\title{
"External labor migration in the context of marketing research (evidence from Russia)"
}

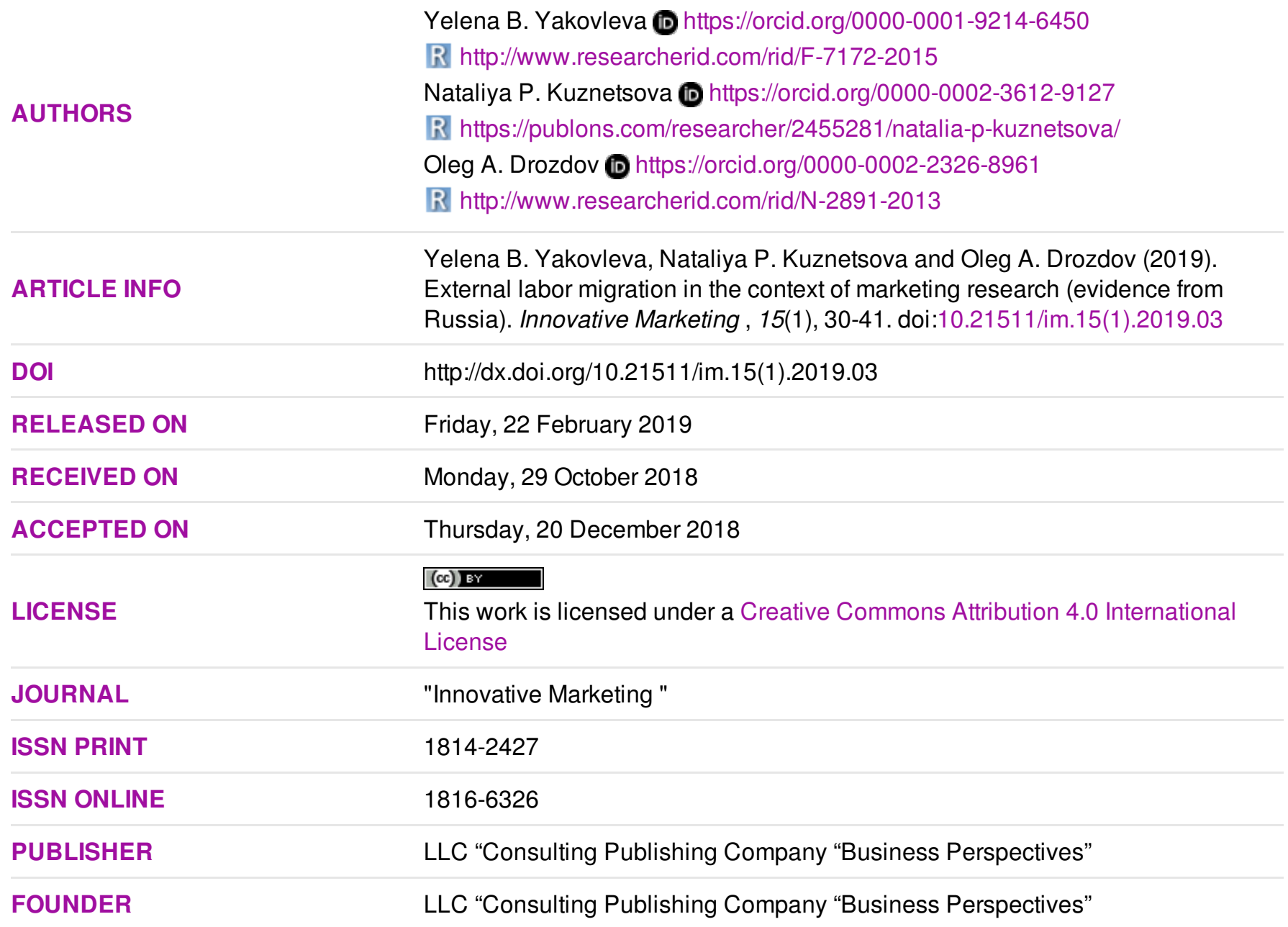

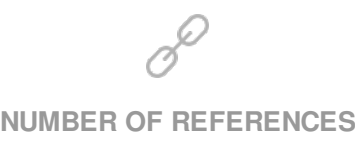

44

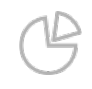

NUMBER OF FIGURES

0

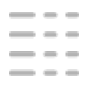

NUMBER OF TABLES

5

(C) The author(s) 2021. This publication is an open access article. 


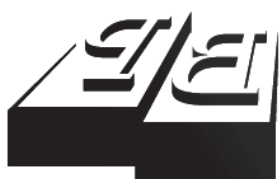

BUSINESS PERSPECTIVES

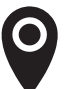

LLC "CPC "Business Perspectives" Hryhorii Skovoroda lane, 10, Sumy, 40022, Ukraine

www.businessperspectives.org

Received on: $29^{\text {th }}$ of October, 2018 Accepted on: $20^{\text {th }}$ of December, 2018

(C) Yelena B. Yakovleva, Nataliya P. Kuznetsova, Oleg A. Drozdov, 2019

Yelena B. Yakovleva, Doctor of Economics, Professor, Saint Petersburg State University, Russian Federation.

Nataliya P. Kuznetsova, Doctor of Economics, Professor, Saint Petersburg State University, Russian Federation.

Oleg A. Drozdov, Ph.D. (Economics), Associate Professor, Saint Petersburg State University, Russian Federation.

\section{(ㄷ)(i)}

This is an Open Access article, distributed under the terms of the Creative Commons Attribution 4.0 International license, which permits unrestricted re-use, distribution, and reproduction in any medium, provided the original work is properly cited.
Yelena B. Yakovleva (Russian Federation), Nataliya P. Kuznetsova (Russian Federation), Oleg A. Drozdov (Russian Federation)

\section{EXTERNAL LABOR MIGRATION IN THE CONTEXT OF MARKETING RESEARCH (EVIDENCE FROM RUSSIA)}

\section{Abstract}

The answer to the question about the labor migrants attraction economic effect on the national economy of the recipient countries remains uncertain. Therefore, the purpose of the study is to determine the necessity and significance of mass labor migration for the economic development of recipient countries in general and Russia in particular. During the study, the authors implemented the following tasks:

1) to identify and assess the contradictions that occur at the micro and macro levels in the host country using migrant labor;

2) to calculate the most essential economic indicators of the efficient use of foreign labor in Russia (based on 2016 data);

3) to assess the contribution of migrant labor to the GDP; and

4) to clarify the impact of all levels of taxes and fees for patents by legal migrants and evasion of such payments by illegal migrants on revenues and expenditures of budgets, accompanied with state budget expenditures to investigate illegal activities (sometimes criminal in nature) with the subsequent deportation of such migrants from the country.

Marketing research has shown that contradictions arising at the micro and macro levels are revealed, which explains the effect of the "migration trap"; the low efficiency of using foreign labor in the Russian economy has been proved, as evidenced by the insignificant share of GDP produced by migrants and significant leaks of a part of GDP from the country's economy through the transfer of funds to donor countries; an imbalance between the needs of the national economy for additional labor by industries and the actual use of foreign labor entering the Russian market is shown; weak influence of the state on the national labor market and the lack of systemic regulation of the quality of training and the scope of migrant labor are revealed.
Keywords

JEL Classification

\section{of GDP, transfers and taxes}

\section{INTRODUCTION}

The globalization of international economic processes leads to the intensification of the movement of financial resources, capital, and labor. The UN report on international migration noted that in 2015 there were 244 million international migrants worldwide (3\% of the total population of the globe), and from 1990 to 2015, the number of international migrants in the world increased by 91 million people, or $60 \%$ (International Migration Report, 2015). On the European sub-continent, particularly intensive movement of migrants began after 2014 . The flows of refugees from Iran, Syria, Afghanistan, and Libya were caused by wars in these regions and the plight of the population. Until 2013, Russia was among the countries that used most actively the migrants labor force and ranked 2 nd in the world. But after 2014, due to 
active migration flows from the Middle East and Central Asian countries to Europe, Russia gave the position to Germany taking the 3rd place.

The problems of migration have long attracted the attention of both Russian and Western researchers who studied migrations socio-political and cultural-psychological components, applying mainly longterm series of migration statistics. Economic problems arising at the micro and macro levels and the impact of labor migration on the economic development of the host countries are fragmented in these studies.

Statistical and analytical data of the World Labor Organization, Russian official statistical yearbooks, materials of the Central Bank of Russia, the Federal Migration Service data, and expert estimates of certain quantitative indicators have made the information and theoretical base of the research. The paper uses economic and statistical analysis to determine the share of GDP, real and potential losses of the state budget of Russia from the use of foreign labor.

The current research allows us: 1) to find out the causal relationships between absolute and relative indicators of gross domestic product output in the Russian Federation, achieved under the influence of using inefficient labor of migrants; 2) to identify the shortcomings and errors of state regulation of migration processes in Russia; and 3) to give practical recommendations for increasing the efficient use of the foreign workers potential in the Russian economy.

\section{THEORETICAL BACKGROUND}

\subsection{The degree of development and the genesis of theoretical and methodological approaches to the study of labor migration in the scientific literature}

The academics in their studies often discuss the demographic, psychological and sociocultural aspects of labor migration. However, these aspects cannot always be expressed in monetary terms through income, costs, profits, etc. A number of Russian researchers studied labor migration problems using marketing tools. Tomilov and Semerkova (2004), Nazarova and Gracheva (2014), Neterebskiy (2016) are among them.

Studies conducted in Western literature were focused mainly on the causes, factors, and incentives that affect the massive movement of labor at a global scale, from one region to another. At the end of the 19th century, Ravenstein $(1876,1885$, 1889) invented 11 general laws of migration, and this approach became classical in the world literature. Among the most significant works in the consequent years, the following investigations should be highlighted: Stouffer (1940) who studied factors that impede migration, Lee (1966) who divided all factors affecting migrants into "push" and "pull" ones, Lewis (1959) and Schultz (1968) who were the Nobel Prize winners in 1979 for developing a model that considered two sectors of the economy: labor-intensive (agriculture) and labor-deficient (industry) (Lewis, 1959). Within the framework of this two-sector model, there is a movement of labor in the closed economic system that causes internal migration of the population. From the subsequent works of the end of the 20th century, the John R. Harris - Michael P. Todaro model (Harris \& Todaro, 1970), the new economic theory of migration by Stark and Bloom (1985) and Masseyet et al. (1993), the theory of a segmented (dual) labor market (Piore, 1979), the world economies approach - l'economie-monde by Braudel (1979), world system theory by Wallerstein (1974), and the theory of migration networks (Massey, 2002) should be highlighted. Although there are many works devoted to migration, only some of them dealt with economic problems. Neoclassical micro level theories consider the desire of an employee (a potential migrant) to maximize one's income moving to another country. The microeconomic theory of individual choice focuses on the problems of rational choice of individuals who, by 
comparing possible losses and gains from moving to another country, strive to maximize the net gain from migration. The new economic theory of migration suggests that decisions about migration are not made by individuals, but by groups of interconnected people who seek to maximize the benefits of movement and minimize risks. All listed theories considered the problem of economic interest from the part of migrants themselves, their families, or national diasporas.

At the same time, there are several studies devoted to the economic aspects of gain/loss model in the recipient countries. First of all, this is "Heavens Door: Immigration Policy and the American Economy" by George Jesus Borjas who considers the economic consequences of immigrants living in the United States. Despite the fact that immigration carries out a number of non-economic consequences (political, humanitarian, etc.), it should contribute to US economic growth, the well-being of all citizens, reduction of inequalities in income distribution and growth in the level of education and qualifications of legal migrants (Borjas, 1999). According to Borjas' calculations, the participation of immigrant workers in the labor market increases US GDP by $11 \%$ (i.e. by 1.6 trillion dollars) annually.

Julian Simon is the next author whose work should be noted. In 1989, Simon published the book "The Economic Consequences of Immigration", where he examined many issues that are extremely urgent for any contemporary economy, including the Russian one. According to the author, the positive effect of the presence of immigrants for the economy of the host country is the following. Migrants are far from "taking off" national economy's social services, but use these services less than national labor force and far overlap their economic "costs" by the value of what they produce, consume and pay as taxes themselves (Simon, 1989). Simon was the first to draw attention to the duality of migration impact, to the fact that immigrants both take and create jobs for the local population. This phenomenon is called "ethnic entrepreneurship" in the modern Russian academic literature.

Russian studies in the field of migration began with the historical works of Kliuchevskiy (1956) who examined the problems of the mass migration of the Russian population to the regions of Siberia, the Far East, the Caucasus and Central Asia. These studies were devoted to the problems of survival of migrants in the new territories (Kliuchevskiy, 1956). After the 1917 revolution, Strumilin (1927) attributed the issues of mass migration to the process of industrialization of the country in the late 20s - early 30s. In the 60s-70s, the Tatiana I. Zaslavskaya school appeared (Zaslavskaya \& Rybakovskiy, 1978), which, applying extensive sociological material, examines the problems of migration from a quantitative point of view in terms of the immigrants' survival indicator. Another important trend in those years was the problem of urbanization, which was reflected in the movement of peasantry to cities. Topilin (1975) devoted the serious research to the study of the labor resource redistribution in the territory of the Soviet Union.

A new stage of research in this field began in the early 90s of the last century, when Russia faced the phenomenon of international labor migration. The works by Iontsev and Ivakhniuk (2008) appeared, which explored the relationship between demographic problems and labor migration. Ivakhniuk (2015) brought up the issues of what kind of migrants Russia needs. Many publications in this area are devoted to the history of theoretical studies of Western scientists (Ivakhniuk, 2015).

Despite the versatility of the research conducted in the last 25 years in the field of international labor migration, a number of issues were not analyzed. The analysis of these and other works, first of all, of Western scholars, makes it possible to note several points. Firstly, sociologists, demographers, philologists, and even linguists were often engaged in the study of migration processes, and the impact of labor migration on the development of host economies in these publications, except for the two authors mentioned above, was virtually not addressed. Secondly, as a rule, the causes of the intercountry movement of the labor force were studied, and the authors of these works did not give answers to the questions: To what extent is a massive labor movement necessary for these countries in terms of migrations impact on economic development? What economic effect of migrant workers involvement has for the national economy at the micro and macro levels? 


\section{CONTRADICTIONS AT THE MICRO AND MACRO LEVELS IN THE PROCESS OF LABOR MIGRANTS USE}

The objective necessity for the use of foreign labor in Russia is caused by several circumstances. Firstly, difficult demographic situation resulted by the country's negative natural population growth rate for more than twenty years (from 1990 to 2016). The number of the resident population decreased by 1.5 million people, the average annual number of people employed in the economy decreased from 75,325 million (1990) to 72,065 million people per annum (Federal State Statistics Service, 2016; Federal State Statistics Service (ROSSTAT), 2017). At the same time, from 2000 to 2016, a number of pensionists increased by almost 5 million people, accompanied with the growing need for their provision in old age (Federal State Statistics Service (ROSSTAT), 2017). Secondly, the predominantly extensive type of public production in Russia remains, which requires additional employees, especially in technologically underdeveloped industries with laborer low qualifications and low wages. Thirdly, the geopolitical position of Russia predetermines the interconnection of the first two problems solution with the attraction of workers from the former Soviet republics (now independent Central Asian states, as well as Ukraine, Belarus and Moldova).

While the research conducted in the last 25 years in the field of international labor migration is versatile, some issues were not considered. One can emphasize two authors mentioned earlier, Borjas and Simon, whose works were devoted to the study of the multiple effects of labor migration on the economies of recipient countries.

As an economic phenomenon, labor migration has both positive and negative consequences when there is a contradiction between the micro and macro levels in the economy of the recipient country.

These contradictions are manifested in the following processes.

Microeconomic problems in the economy are actualized by business that is interested in reducing costs in order to get higher profits than competitors. Therefore, any entrepreneur tries to reduce his costs, primarily due to cheaper labor. This causes additional competition in the national market, and acts towards lowering the wages of "local" workers. For a business that uses migrant workers, this gives a competitive cost advantage, if the possible reduction in the quality of work is not considered. At the micro level, this policy leads to a decrease in incentives for the introduction of new technologies, the use of scientific and technological progress, which requires a more prepared and highly skilled workforce. The need to use high-quality and expensive human capital is in conflict with the quality of workers migrating to Russia. In particular, only $26.8 \%$ of migrants from the CIS countries, have higher professional education, $25.6 \%$ have secondary and primary vocational education, $28.5 \%$ have general secondary education (full and incomplete) and 1.8\% of migrants have primary or no education at all (Federal State Statistics Service, 2017). The Russian labor force has higher parameters: $32.2 \%$ of workers have higher education, $44.8 \%$ - secondary vocational education, $22.68 \%$ have secondary and basic general education (Federal State Statistics Service (Statistical Book), 2017). The high quality of employees requires higher wage, which capitalist couldn't afford. In such a situation, the shortterm interests and benefits of business have the upper hands over the long-term prospects for its development. That is why foreign labor in Russia is used mainly in technologically backward sectors, where wages are lower than the average for the economy (see Table 1).

Migrants in the Russian economy work mainly in the following sectors: $15.9 \%$ (where $15.9 \%$ of Russians work, of the total number of employed in all sectors) of persons work in the service sector (retail trade, repair of motor vehicles, household goods and personal items), 7.2\% (7.14\% of Russians) work for construction, $6.5 \%$ (6.5\% of Russians) are involved in agriculture, $14.4 \%$ (14.3\% of Russians) - in manufacturing sectors (Federal State Statistics Service (Statistical Book), 2017). In 2016, the average wage in the RF economy amounted to 36,746 rubles, and the salary in the sectors mentioned is given in Table 1. As a rule, the wage of migrants is approximately $70 \%$ of the wages of Russians. The above data confirm the idea that foreign labor is 
Table 1. Relative employment rates of migrants and sectoral wages in the Russian Federation in 2016 (\%)

\begin{tabular}{|c|c|c|c|}
\hline No. & Economic sector & $\begin{array}{c}\text { Share of migrants employed } \\
\text { in the sector, \% of the overall } \\
\text { number of employed }\end{array}$ & $\begin{array}{l}\text { The ratio of wages in the sector to the } \\
\text { average wage in the economy of the } \\
\text { Russian Federation in } 2016\end{array}$ \\
\hline 1 & Manufacturing industry & 14.4 & 94.2 \\
\hline 2 & Construction & 7.2 & 88.0 \\
\hline 3 & $\begin{array}{l}\text { Service sector (retail trade, home/other } \\
\text { technique appliance maintenance, etc.) }\end{array}$ & 15.9 & 81.8 \\
\hline 4 & Agriculture & 6.5 & 59.2 \\
\hline
\end{tabular}

used mainly where Russian workers are not very interested in taking up jobs due to difficult working conditions and low wages.

At the macroeconomic level, the following contradiction is observed. The low technical and technological level of individual enterprises leads to low labor productivity and production efficiency, as well as to insufficient innovation implementation in the entire economic system. In addition, the migratory influx of labor into Russia induces the emergence of multiple macroeconomic disfunctions, namely 1) impressive flowering of the shadow economy; 2) losses of budget funds of all levels due to the fact that illegal migrants do not buy patents, do not transfer taxes to the budget revenues; 3) the most powerful outflow of financial resources from the country as transfers of migrants (i.e., the real loss of a part of GDP as a result of inter-country transfers), etc.

The contradictions between the micro and macro levels of the domestic economy create the effect of a "migration trap". Its economic meaning is observed in the contradiction between business and the state arising out of the use of foreign labor in the national economy. The positive effect of this trap depends on the institutional regulations for migrant's admission, which are set by the state, i.e. the extent to which legislation contributes to the legal high-performance activities of foreign labor. A negative effect occurs when the labor of migrants in this economic system is not effective enough. There are several reasons for this situation, in particular difficulties of hiring procedures for foreign labor, which are easier for migrants to "get around" than to use in reality, low labor productivity, low wages, insufficient tolerance and negative public perception of migrants, up to active protests against such workers, etc.

\section{IMPORTANT ECONOMIC INDICATORS OF LABOR MIGRATION USAGE IN THE RUSSIAN ECONOMY}

These contradictions are most clearly manifested through economic indicators of the migrant labor use.

Important economic indicators of labor migration include: 1) the share of GDP produced by legal and illegal migrants; 2 ) taxes and payments paid by migrants to budgets of different levels.

To study these indicators, we will assess the migration situation in Russia, according to the Federal Migration Service (FMS), characterized by the following data (see Table 2).

Table 2. Data on the migration situation in Russia and transfers of migrants in 2015 and 2016

Source: Compiled based on the Information Support for Migrants (2017) data.

\begin{tabular}{|c|c|c|c|c|}
\hline No & Indicators & 2015 & 2016 & $\begin{array}{l}\text { Data } \\
\text { change }\end{array}$ \\
\hline 1 & $\begin{array}{l}\text { Foreign citizens } \\
\text { entered }(\mathrm{mln} \\
\text { people) }\end{array}$ & $17,333,777$ & $16,290,031$ & $-1,043,746$ \\
\hline 2 & $\begin{array}{l}\text { Foreign citizens } \\
\text { deported (thousand } \\
\text { people) }\end{array}$ & 117,493 & 60,042 & $-57,451$ \\
\hline 3 & $\begin{array}{l}\text { Work permits } \\
\text { issued (thousand } \\
\text { people) }\end{array}$ & 214.5 & 149.0 & -65.5 \\
\hline 4 & $\begin{array}{l}\text { Patents obtained } \\
\text { (thousand units) }\end{array}$ & $1,788.2$ & $1,510.3$ & -277.9 \\
\hline \multirow[t]{3}{*}{5} & \multicolumn{4}{|c|}{$\begin{array}{l}\text { Cross-border transactions of individuals } \\
\text { (transfers from the Russian Federation) (USD mln) }\end{array}$} \\
\hline & total & 9,719 & $7,335.3$ & $-2,383.7$ \\
\hline & in CIS countries & 7,978 & $5,596.0$ & $-2,382.0$ \\
\hline
\end{tabular}

Table 2 shows that the flow of foreign labor decreased by more than one million people in 2016 compared to 2015. Accordingly, the number of registered patents (by 277.9 thousand units) and work permits (by 
65.5 thousand units) decreased. This is due to two circumstances: firstly, the procedures for obtaining official documents for work were complicated, and secondly, there was a sharp depreciation of the ruble against the dollar (euro) in 2015-2016. These led to a decrease in the volume of remittances of foreign citizens, mainly due to migrants from the CIS.

Having characterized the quantitative parameters of migration flows, let's consider the most significant economic indicators. The calculation of the amount of GDP produced by migrants in Russia is complicated by the fact that the number of illegal migrants is not confirmed statistically, and we can only rely on expert estimates. The parameters were calculated by the number of migrants officially participating in the Russian economy and by the volume and share of GDP produced by them based on the 2016 data (see Table 3).

Table 3. Number and share of Russia' GDP produced by legal migrants in 2016

Source: Compiled based on Stark and Bloom (1985)

\begin{tabular}{|c|c|c|}
\hline No: & Indicators & $\begin{array}{l}\text { Absolute } \\
\text { and relative } \\
\text { indicators }\end{array}$ \\
\hline 1 & GDP in 2016 market prices (bln rubles)* & 86,044 \\
\hline 2 & $\begin{array}{l}\text { Average annual number of employed } \\
\text { (thousand people) }\end{array}$ & 68,430 \\
\hline \multirow{3}{*}{3} & $\begin{array}{l}\text { The number of migrants officially } \\
\text { engaged in economic activities } \\
\text { (thousand people), including: }\end{array}$ & $1,687.3$ \\
\hline & work permits issued (thousand people) & 143.9 \\
\hline & patents obtained (thousand units) & $1,543.4$ \\
\hline 4 & $\begin{array}{l}\text { Share of migrants in the average annual } \\
\text { number of engaged in economic } \\
\text { activities }(\%)\end{array}$ & 2.46 \\
\hline 5 & $\begin{array}{l}\text { Share of GDP produced by migrants (bln } \\
\text { rubles) }\end{array}$ & $2,116.68$ \\
\hline 6 & Share of GDP produced by migrants $(\%)$ & 2.46 \\
\hline
\end{tabular}

Note: ${ }^{*}$ GDP in market prices is calculated as output in basic prices (152,325 billion rubles) - intermediate consumption $(74,817$ billion rubles $)+$ net taxes on products $(8,535$ billion rubles $)=86,044$ billion rubles.

The calculations show that a foreign labor force legally taken on the staff creates $2.46 \%$ of Russia's GDP, which is expressed in 2,116.68 billion rubles. The problem is that not only legal, but also illegal migrants are involved in the process of creating an additional product and providing services. The number of these migrants and the indicator of the GDP they create are difficult to determine. Estimates of the total number of illegal migrants range from 1.5 to 15 million.
Some literature sources estimate that this indicator is equal to 4-5 million. In the final report on the migration situation, results and main directions of migration policy for 2016, the role of migrants is estimated taking into account the fact that there are 10 million legal and illegal migrants in Russia. According to some experts, labor migrants create now 7.56 percent of Russia's GDP - in monetary terms 8.25 trillion rubles (RSS FEED, 2013).

The figures provided by Romadanovskiy (2013), the head of the migration service, are most credible. He believes that the number of illegal migrants in Russia amounted to 3 million people in 2016 . Taking this estimate as a basis, it is possible (using the Table 2 data) to recalculate the share of GDP produced by both legal and illegal migrants for 2016 . The number of legal and illegal migrants will be $4,687.3$ thousand people, the average annual number of employed in the economy will also increase by 3 million people, and will be 71,430 thousand people. The share of working migrants in the total number of employed will be equal to $6.5 \%$. Based on the fact that in 2016 the GDP amounted to 86,044 billion rubles, additional 5,592.8 billion rubles were received due to the use of foreign labor, which is $6.5 \%$ of Russia's total GDP. The calculations made should take into account several assumptions: first, the number of illegal migrants taken into account is based on the expert's opinion and is not appeared to be a result of regular statistical measurements; second, the productivity and wages of migrants are lower than those of Russian workers, therefore, their share in GDP will be slightly lower. These assumptions reduce the role of foreign labor in the Russian economy.

Having assessed what proportion of GDP foreign labor creates, it is necessary to determine how much damage it brings to the Russian economy. First, the transfer of funds earned in Russia to other countries. If to convert cross-border transfers (The Central Bank of the Russian Federation, 2017) from a dollar to a ruble dimension (at the average annual exchange rate of 2016: one ruble $=67.03$ dollars), one gets 493 billion rubles, which is $5.7 \%$ of the country's GDP. In this case, only official monetary transfers are considered, and cash exported is not subject to statistical accounting. Since we conduct further calculations relative to the majority of migrants coming from CIS countries and working 
under patents, transfers in neighboring countries should be taken into account, which make up 76\% of the total amount of transfers. In this case, the ruble equivalent of moving funds will be equal to 375 billion rubles, which is $4.3 \%$ of GDP. At the same time, the effect of the multiplier in the Russian economy, which increases the impact of consumer spending on the dynamics of economic development, is not evaluated, and the funds taken out of the national economy are, of course, potential consumer spending.

Second, some damage is caused as a result of the need to deport some migrants who violate the country laws. In 2016, for violations of migration laws and for other offenses, 6,042,000 thousand foreign citizens were expelled from the country. This procedure is carried out at the expense of the state budget (the revenue part of which amounted to $13,738.5$ billion rubles in 2016) (Federal budget of Russia for 2016 in figures for all items, 2016). According to Romadanovskiy (2013), the deportation of one migrant costs 1,000 dollars, i.e. 67,030 thousand rubles (at the 2016 exchange rate). In this case, the total amount of damage amounts to more than 4,033.6 million rubles, which accounted for $0.03 \%$ of the state budget revenues.

One can emphasize the real and potential losses of state budget from the arrival of migrants. The real losses include the costs on deportation of foreigners who violated Russian legislation. The potential losses include non-payment of illegal migrants for taxes (which could replenish the budget revenue) and additional funds from the patent acquisition.

Third, we took for granted the expert opinion of Romadanovskiy ${ }^{1}$ about the quantity of illegal migrants in the Russian economy as 3 million considering this figure as the basis of calculations in 2016. These persons do not pay taxes and do not pay for acquisition of a patent. The cost of the patent differs for different regions, and ranges from 1,948 rubles (regions of poor demand, such as the Altai Republic, Kabardino-Balkaria, North Ossetia and others, where the unemployment rate among local residents is quite high - and the income level is low) up to 8,762 rubles (Yakutia, a region characterized by high incomes and a rotating job schemes for certain activities. A significant mass of migrants formalizes their labor relations through the acquisition of patents (1,543.4 thousand people). The average cost of a patent in Russia is about 3,000 rubles. Revenues of regional level budgets (which are included into the consolidated budget) amount to 4,630 million rubles $(0.03 \%$ of state budget). Losses of local budgets of different levels from non-acquisition of patents by illegal migrants amount to 9,000 million rubles ( 3,000 rubles multiplied by 3 million illegal migrants), which is $0.06 \%$ of the total revenues of the consolidated budget. Fourth, foreign workers pay monthly a fixed advance payment from the wages received, the amount of which varies by regions. For example, in Buryatia, this payment was 1,568.4 rubles in 2016, in the Republic of Sakha (Yakutia) - 7,056.23 rubles, in Moscow (and Moscow region) - 4,000.05 rubles, in St. Petersburg (and Leningrad region) it amounted to 3,000 rubles (The size of fixed advance payments, 2016 Legal Labor, n.d.). In 2016, the consolidated budget revenue for these payments amounted to 45.9 million rubles (Federal Tax Service, 2017), which is $0.00016 \%$ of consolidated state budget. The amount of money paid for one patent (considering the different value of fixed advance payments on personal income tax in different regions) is an average of 29,747 rubles per year (Consolidated budget of the Russian Federation for 2016) Infotables.ru, n.d.).

Then, the potential losses of the consolidated state budget from unpaid illegal migrant funds amount to 89.25 billion rubles $(0.31 \%$ of the consolidated budget) in 2016. Calculated data are summarized in Table 4.

Summarizing the data obtained, one can conclude that the contribution of labor migrants to the Russian economy is extremely low and amounts to only $2.2 \%$ of the GDP produced. The income side of the state budget is replenished by paying fixed payments by migrants and slightly by the proceeds from the sale of patents. The costs of deportation are of a larger amount than income from various types of migrant worker activities.

The low efficiency of using the migrant labor is due to the fact that in Russia there are no government tools for allocation of incoming labor resources to

1 Taking into account that it is impossible to trace illegal migrants statistically we have to rely on the expert opinions of K. Romadanovskiy and the deputy head of the Federal Migration Service A. Kuznetsov. 
Table 4. Results of using the migrant workers in the Russia's economy in 2016

\begin{tabular}{|c|c|c|c|c|c|c|c|c|c|}
\hline \multirow{3}{*}{ No. } & \multirow{3}{*}{ Indicators } & \multicolumn{2}{|c|}{$\begin{array}{c}\text { Share of GDP } \\
\text { produced by } \\
\text { migrants }\end{array}$} & \multirow{2}{*}{\multicolumn{2}{|c|}{$\begin{array}{c}\text { Consolidated state } \\
\text { budget income }\end{array}$}} & \multicolumn{4}{|c|}{ Consolidated state budget losses } \\
\hline & & \multirow[b]{2}{*}{$\begin{array}{l}\text { In } \\
\text { rubles }\end{array}$} & \multirow[b]{2}{*}{$\begin{array}{l}\text { In } \% \\
\text { of GDP }\end{array}$} & & & \multicolumn{2}{|c|}{ Real losses } & \multicolumn{2}{|c|}{ Potential losses } \\
\hline & & & & $\begin{array}{l}\text { In } \\
\text { rubles }\end{array}$ & $\begin{array}{c:}\text { In } \% \text { of } \\
\text { the state } \\
\text { budget }\end{array}$ & $\begin{array}{l}\text { In } \\
\text { rubles }\end{array}$ & $\begin{array}{c}\text { In } \% \text { of } \\
\text { the state } \\
\text { budget }\end{array}$ & In rubles & $\begin{array}{c}\text { In } \% \text { of } \\
\text { the state } \\
\text { budget }\end{array}$ \\
\hline 1 & $\begin{array}{l}\text { Share of GDP produced by legal } \\
\text { migrants, bln rubles }\end{array}$ & $2,116.68$ & 2.46 & - & - & - & - & - & - \\
\hline 2 & $\begin{array}{l}\text { Share of GDP produced by both } \\
\text { legal and illegal migrants, bln } \\
\text { rubles }\end{array}$ & $5,592.8$ & 6.5 & - & - & - & - & - & - \\
\hline 3 & $\begin{array}{l}\text { Share of GDP exported through } \\
\text { transfers, bln rubles }\end{array}$ & 375.9 & 4.3 & - & - & - & - & - & - \\
\hline 4 & $\begin{array}{l}\text { State budget costs for the } \\
\text { deportation of migrants, mln } \\
\text { rubles }\end{array}$ & - & - & - & - & $4,033.6$ & 0.03 & - & - \\
\hline 5 & $\begin{array}{l}\text { Budget income of different } \\
\text { levels from the acquisition of } \\
\text { patents by migrants, mln rubles }\end{array}$ & - & - & 4.6 & 0.00003 & 45.9 & 0.0003 & - & - \\
\hline 6 & $\begin{array}{l}\text { Loss of budgets of different } \\
\text { levels from funds not paid for } \\
\text { the patent acquisition, bln } \\
\text { rubles }\end{array}$ & - & - & - & - & - & - & 9.0 & 0.06 \\
\hline 7 & $\begin{array}{l}\text { Consolidated state budget } \\
\text { revenues due to payment } \\
\text { of personal income tax by } \\
\text { migrants, mln rubles }\end{array}$ & - & - & 45.9 & 0.0003 & - & - & - & - \\
\hline 8 & $\begin{array}{l}\text { State budget losses from illegal } \\
\text { migrants due to failure to make } \\
\text { fixed payments, bln rubles }\end{array}$ & - & - & - & - & - & - & 89.25 & 0.31 \\
\hline & Total & $\begin{array}{c}5,216.9 \\
\text { bln rubles }\end{array}$ & $2.2 \%$ & $\begin{array}{l}50.5 \mathrm{mln} \\
\text { rubles }\end{array}$ & $0.00033 \%$ & $\begin{array}{c}4,078.9 \\
\text { mln rubles }\end{array}$ & $0.03 \%$ & $\begin{array}{c}98.25 \mathrm{bln} \\
\text { rubles }\end{array}$ & $0.37 \%$ \\
\hline
\end{tabular}

those areas of activity that is really needed. If we compare the types of economic activity in which there are vacancies and the distribution of migrants in different areas of the actual use of their labor, then the existing disparities are visible (see Table 5).
Table 5 shows that despite very close values of vacant jobs and the number of labor migrants (814.6 thousand vacancies and 939.3 thousand migrants), there is no coincidence between these values by type of economic activity. For example, with the need for 38.7 thousand people for whole-

Table 5. Number of employees required for vacant jobs and the distribution of migrants by economic activities

\begin{tabular}{|c|c|c|}
\hline Economic activity & $\begin{array}{l}\text { Number of employees required for } \\
\text { vacant jobs, by economic activity, } \\
\text { thousand people }\end{array}$ & $\begin{array}{l}\text { Distribution of migrants by } \\
\text { economic activity, thousand } \\
\text { people }\end{array}$ \\
\hline Total & 814.6 & 939.3 \\
\hline Agriculture, hunting and forestry & 20.3 & 74.0 \\
\hline Fish-farming and fishing & 0.51 & 1.2 \\
\hline Construction & 15.0 & 163.3 \\
\hline $\begin{array}{l}\text { Wholesale and retail trade, repair of motor } \\
\text { vehicles, motorcycles, household goods and } \\
\text { personal items }\end{array}$ & 38.7 & 352.6 \\
\hline Manufacturing & 73.1 & 64.8 \\
\hline Hotels and restaurants & 10.8 & 58.7 \\
\hline Transport and communications & 87.5 & 59.3 \\
\hline Real estate transactions, rent, and service provision & 90.5 & 88.2 \\
\hline Education & 47.5 & 7.9 \\
\hline Health care and social services & 159.2 & 3.5 \\
\hline $\begin{array}{l}\text { Provision of other utility, social and personal } \\
\text { services }\end{array}$ & 28.2 & 65.9 \\
\hline
\end{tabular}


sale and retail trade, this sector employs 9 times more (352.6 thousand migrants), in construction, with an application for 15.0 thousand people, they actually employ more than 10 times more (163.3 thousand foreign workers). At the same time, in a socially important industry like health care, there is a need for 159.2 thousand people (we mean nursing staff), but only 3.5 thousand people were employed. This most likely is due to the lack of information among visiting workers about the real need for additional labor in certain industries. As a result, the employment of migrants goes spontaneously, which significantly reduces their efficient use.

\section{CONCLUSION}

Summing up the presented study, one can come to the following conclusions.

1. The paper has proposed an algorithm for determining the share of GDP produced by migrants in the national economy and the loss of the national budget from illegal migration. The calculations showed that in the Russian economy, the use of additional labor coming to the labor market is extremely inefficient.

2. The study described positive effect of migration at the business level (micro level), and negative one for many macroeconomic indicators, revealing contradictory tendencies in migration. The calculations made show that the positive effects on the scale of the entire economy include the fact that in 2016, at the expense of labor migrants, the Russian economy produced $6.5 \%$ of the total GDP. At the same time, there are significant drawbacks at the macro level: $2.46 \%$ of GDP leaves the country due to the transfer of funds to the countries that are donors of labor migrants. Ultimately, the net balance of GDP is only $2.2 \%$. Regarding the state budget, the following results can be summed up. The state is forced to spend additional funds on the deportation of some foreign citizens who violate the law; illegal migrants do not pay the necessary taxes, and the budget receives additional income only from officially registered migrants and from the sale of patents. These consolidated budget revenues are very slight and amount only to $0.0003 \%$ of the state budget. State budget losses amount to 4,078 million rubles, or $0.03 \%$ of its revenue side, and the potential losses of the consolidated state budget are quite large making up 98.25 billion rubles $(0.37 \%$ of the state budget).

3. These contradictory phenomena, tendencies and indicators could be explained by the drawbacks of state governance. One can note the major negative feature of the Russian migration processes regulation: inefficient use of migrant labor is due to the fact that the state, being interested in replenishing the labor market with additional labor, has practically been eliminated from any of its regulation.

4. There are several ways to reform the system of relations between state institutions interested in foreign labor: 1) institutional methods meaning territorial and sectoral regulation, i.e. the redistribution of migrant flows to those territories and areas of activity that really need an additional influx of labor. Such measures should not be administrative in a market economy; 2) informational method using the information-communication technologies causing the elimination of sectoral imbalances in employment in the Russian economy, by timely informing migrants about the needs of certain enterprises, and the conditions of their potential employment; 3) a number of economic methods such as: lower cost of tax payments or refusal of a patent, subject to the legalization of activities; the grant of Russian citizenship, subject to being employed in these regions for a number of years; providing social benefits subject to fulfilling certain terms of the contract, etc. 


\section{PRACTICAL RECOMMENDATIONS}

Legalization of foreign labor arriving in the country is the main problem of economic relations arising between home-country's migrants and the host country (Russia). The host recipient country is vitally interested in the official registration and taking labor migrants on the staff. The multiplicity of regulatory documents, which change almost every year, and the complexity of accounting and tax deductions are a specific barrier for both the migrants themselves and the bureaucratic official bodies that supervise their stay in a country. In the end, financial losses are born by the state and municipal budgets. To solve this problem, it is necessary to take some measures.

First, it is necessary to simplify the registration procedures (passing exams, obtaining patents) for incoming labor from neighboring countries (particularly from the former USSR republics). For sure, there must be certain barriers for migrants namely: the state of health, knowledge of the country of destination language, but these obstacles should not be obstructing in nature.

Second, calculations show that if Russian tax legislation is extended to all labor migrants, then the economic benefits will be obvious. If we take the data for 2016 as a basis, then the total number of migrants employed in the economy is 4.5 million. In 2016, the average wage of workers was 36,709 rubles. Even the payment of income tax (13\%) for 12 months will be 2,57697 million rubles of additional income that goes to meet the municipal budgets needs. We must add to this figure about $30 \%$ of the charges paid by employers to the entity's wages fund directed to the federal budget. According to the most simplified settlement system, this number will amount to 594.6 billion rubles of additional income to the state budget, which will be $0.004 \%$ of the state budget. This amount is more than 10 times higher than revenues with the currently established tax system.

Third, the training of workers of the necessary specialties, directly in the territory from which they come, is needed. This requires intergovernmental agreements legalizing such educational activities in the territory, for example, of the Central Asian states of the CIS, from which more migrants come to Russia (Uzbekistan, Tajikistan, Kyrgyzstan and other countries with a high unemployment rate and where there is governmental engagement in addressing this issue). Such activity was initiated at the regional level between the authorities of St. Petersburg and the top leaders of Uzbekistan. The training center for migrants has been opened in Samarkand, where a preliminary interview, questionnaire, pre-training, consulting, medical examination and testing in Russian language will be conducted (Gurkin, 2017). This is the first experiment towards achieving a real impact on the regulation of migration flows.

Such measures will provide additional funds for the Russian economy development, reduce the size of the shadow business, and will enable migrants to enjoy social benefits legally on the territory of the host country.

\section{REFERENCES}

1. Borjas, G. J. (1999). Heaven's Door: Immigration Policy and the American Economy. Princeton. NJ: Princeton, University Press.

2. Braudel, F. (1979). Civilisation matérielle, économie et capitalisme (197 p.). XVe-XVIIIe siècles.

3. Federal budget of Russia for 2016 in figures for all items (2016). Retrieved from http://111999.ru/ economy/rossii-na-2016-god-v- cifrax (accessed on December 10, 2018) [in Russian].

4. Federal State Statistics Service (2016). Russian statistical yearbook, 2016. Retrieved from http://www. gks.ru/free_doc/doc_2017/year/ year17-all.rar (accessed on December 4, 2018)

5. Federal State Statistics Service (2017). Численность населения и миграция в Российской
Федерации в 2017 году [Chislennost naseleniya i migratsiya $v$ Rossiyskoy Federatsii v 2017 godu]. Retrieved from http://www.gks.ru/ free_doc/doc_2018/bul_dr/bulmigr 18.rar (accessed on December 10, 2018).

6. Federal State Statistics Service (Abridged Statistical Book) (2017). Pоссия в ииффраx [Rossiya $v$ tsifrakh]. Retrieved from http://www. gks.ru/free_doc/doc_2017/rusfig/ 
rus17.pdf (accessed on December 10, 2018).

7. Federal State Statistics Service (ROSSTAT) (2017). Russian statistical yearbook, 2017. Retrieved from http://www.gks.ru/free_doc/ doc_2017/year/year17.pdf (accessed on December 4, 2018).

8. Federal State Statistics Service (Statistical Book) (2017). Труд и занятость в России 2017 [Trud i zanyatost v Rossii]. Rosstat, 46, 68. Retrieved from http://www.gks.ru/ free_doc/doc_2017/trud_2017.pdf (accessed on December 9, 2018).

9. Federal Tax Service (2017). Accrual and receipt of taxes, fees and other obligatory payments to the consolidated budget of Russia (Form No. 1-nm). Retrieved from https://www.nalog.ru/html/ sites/www.new.nalog.ru/docs/ otchet/1nm010117.xls (accessed on December 10, 2018).

10. Gurkin, S. (2017). Петербург начал готовить трудовых мигрантов в Узбекистане: зачем это нужно? [Peterburg nachal gotovit trudovykh migrantov $v$ Uzbekistane: zachem eto nuzhno?]. Retrieved from https://regnum.ru/ news/2343026.html (accessed on December 10, 2018).

11. Harris, J. R., \& Todaro, M. P. (1970). Migration, Unemployment and Development: A Two-Sector Analysis. American Economic Review, 60(1), 126-142. Retrieved from https://www.jstor.org/ stable/1807860?seq=1\#page_scan_ tab_contents

12. Information Support for Migrants (2017). Статистика ФМС за 2016 и 2015 г2. по миграционной ситуаиии в Poсcuи [Statistika FMS za 2015 i 2016 gg. po migratsionnoy situatsii $v$ Rossii]. Retrieved from https://yamigrant. ru/svodka-po-migratsionnojsituatsii-v-rossii-za-2016-god.html (accessed on December 9, 2018).

13. Infotables.ru (n.d.).

Консолидированньй бюджет Российской Федерации в 2016 (Таблица) [Konsolidirovannyy byudzhet Rossiyskoy Federatsii v 2016 (Tablitsa)]. Retrieved from http://infotables.ru/statistika/79ekonomicheskaya-statistika- rossii/906-konsolidirovannyjbyudzhet-rf\#hcq=f9Oupcr

14. International Migration Report, 2017: Highlights key facts. United Nations, Department of Economic and Social Affairs, Population Division (2017). International Migration Report 2017: Highlights (ST/ESA/SER.A/404). Retrieved from www.unpopulation.org

15. Iontsev, V. A., \& Ivakhnyuk, I. V. (2008). Изучение миграции населения [Izuchenie migratsii naseleniya]. Uroven zhizni naseleniya regionov Rossii, 3-4, 72-80.

16. Ivakhnyuk, I. V. (2008). Eurasian migration system: theory and policy. Moscow: MAKS Press.

17. Ivakhnyuk, I. V. (2015). Развитие миграционной теории в условиях глобализации [Razvitie migratsionnoy teorii $\mathrm{v}$ usloviyakh globalizatsii]. Vek globalizaztsii, 1, 36-50. Retrieved from https:// www.socionauki.ru/journal/articles/269703/

18. Kliuchevskiy, V. O. (1956). Writings (Vol. 1). Moscow [in Russian].

19. Lee, E. (1966). A Theory of Migration. Demography, 3(1), 47-57. Retrieved from http:// links.jstor.org/sici?sici=0070$3370 \% 281966 \% 293 \% 3 \mathrm{~A} 1 \% 3 \mathrm{C} 47 \%$ 3АATOM\%3Е2.0.CO\%3B2-B

20. LegalLabor (n.d.). Размеры фиксированного авансового платежа по НДФЛ для иностранных работников в 2016 году по регионам [Razmery fiksirovannogo avansovogo platezha po NDFL dlya inostrannykh rabotnikov $v 2016$ godu po regionam]. Retrieved from http://legallabor.ru/ sobytiya-i-informatsiya/40razmery-fiksirovannogo-avansovogo-platezha-po-ndfl-ezhemesyachnaya-plata-za-patent-dlyainostrannykh-rabotnikov-v-2016-godu (accessed on December 10, 2018).

21. Lewis, W. A. (1959). The Theory of Economic Growth (402 p.). N.Y.

22. Massey, D. (2002). A Synthetic Theory of International Migration. In V. Iontsev (Ed.), The World in the Mirror of International Migration, Scientific
Series "International Migration of Population: Russia and the Contemporary World" (Vol. 10) (pp. 143-153). Moscow: MAX Press.

23. Massey, D. S., Arango, J., Hugo, G., Kouaouci, A., Pellegrino, A., \& Taylor, E. J. (1993). Theories of International Migration: A Review and Appraisal. Population and Development Review, 19(3), 431-466.

24. Nazarov, W. A., \& Gracheva, N. А. (2014). Региональный маркетинг персонала: проблемы постобразовательной миграции [Regionalnyi marketing personala: problemy postobrazovatelnoy migratsii]. Fundamentalnye issledovaniya, 11(5), 1124-1128. Retrieved from https://elibrary.ru/ item.asp?id=22490636

25. Netrebsky, O. V. (2016). Подходы к решению проблем внешней трудовой миграции в России [Podkhody k resheniyu problem vneshney trudovoy migratsii $\mathrm{v}$ Rossii]. Migratsiya i sotsialnoekonomicheskoe razvitie, 1(4), 227-238. https://doi.org/10.18334/ migration.1.4.38092

26. Piore, M. (1979). Birds of passage. Migrant labor and industrial societies. N.Y.: Cambridge University Press.

27. Ravenstein, E. (1876). The Birthplace of the People and the Laws of Migration. The Geographical Magazine, 3, 173-233. Retrieved from https://www.amazon.co.uk/ Birthplaces-People-Laws-Migration/dp/1120172853

28. Ravenstein, E. (1885). The Laws of Migration. Journal of the Royal Statistical Society, 48(2), 167-235. Retrieved from https://www. jstor.org/stable/pdf/2979181. pdf?seq=1\#page_scan_tab_contents

29. Ravenstein, E. (1889). The Laws of Migration: Second Paper. Journal of the Royal Statistical Society, 52(2), 241-305. https://doi. org/10.2307/2979333

30. Romadanovskiy, K. (2013). Депортация одного нелегала обходится России в тысячу долларов [Deportatsiya odnogo 
nelegala obkhoditsya Rossii v tysyachu dollarov]. Retrieved from https://www.afanasy.biz/news/ society/?ELEMENT_ID $=66683$ (accessed on January 25, 2019).

31. Romadanovskiy, K. (2013). Количество легальных и нелегальных мигрантов в РФ сравнялось [Kolichestvo legalnykh i neleganlykh migrantov $v R F$ sravnyalos]. Retrieved from http:// expert.ru/2014/11/20/kolichestvolegalnyih-i-nelegalnyih-migrantov-v-rf-sravnyalos/

32. Romadanovskiy, K. (2013). ФМС насчитала в России 3,6 миллионов нелегалов и признала существование межэтнических конфликтов [FMS naschitala $v$ Rossii 3.6 millionov nelegalov $i$ priznala sushchestvovanie mezhetnicheskikh konfliktov]. Retrieved from https://www.newsru.com/ russia/16dec2013/fmsnelegaly. html (accessed on January 25, 2019).

33. RSS FEED (2013). Трудовые мигранты создают 7.56 процента ВВП России [Trudovye migranty sozdayut 7.56 protsenta VVP Rossii]. Retrieved from http:// vgil.ru/2013/11/10/trudovyemigranty-sozdayut-756-procentavvp-rossii (accessed on December 10, 2018).
34. Schultz, T. W. (1968). Economic Growth and Agriculture (306 p.). New York: McGraw-Hill.

35. Simon, J. L. (1989). The Economic Consequences of Immigration. N.Y.: Blackwell.

36. Stark, O., \& Bloom, D. E. (1985). The New Economics of Labor Migration. American Economic Review, 75(2), 173-178. Retrieved from https://www.jstor.org/ stable/1805591?seq=1\#page_scan_ tab_contents

37. Stouffer, S. (1940). Intervening Opportunities: A Theory Relating Mobility and Distance. American Sociological Review, 5, 845-867. https://doi.org/10.2307/2084520

38. Strumilin, S. G. (1927). To the prospective five-year plan of the State Planning Committee on 1925/27 - 1930/31. Planned Economy, 3, 17-54.

39. The Central Bank of the Russian Federation (2017). Трансграничные переводы физических лии, (резидентов и нерезидентов) [Transgranichnye perevody fizicheskikh lits (rezidentov i nerezidentov)]. Retrieved from http://www.cbr.ru/statistics/ Default.aspx?Prtid=tg (accessed on December 10, 2018).

40. Tomilov, V. V., \& Semerkova, L. N. (2004). Маркетинг рабочей силы [Marketing rabochey sily] (96 sec.). Uch. allowance. Moscow. Retrieved from http://udik.com. ua/books/book-796/

41. Topilin, A. (1975). Территориальное распределение трудовых ресурсов в СССР [Territorialnoe raspredelenie trudovykh resursov v SSSR]. Moscow: Economics.

42. United Nations, Department of Economic and Social Affairs, Population Division (2016). International Migration Report 2015: Highlights (ST/ESA/SER.A/375). Retrieved from http://www. un.org/en/development/desa/ population/migration/publications/migrationreport/docs/MigrationReport2015_Highlights.pdf (accessed on December 10, 2018).

43. Wallerstein, I. (1974). The Modern World System I. Capitalist Agriculture and the Origins of the European World Economy in the Sixteenth Century (410 p.). N.Y.: Academic Press.

44. Zaslavskaya, T. I., \& Rybakovskyy, L. L. (1978). Процессы миграции и их регулирование в социалистическом обществе [Protsessy migratsii i ikh regulirovanie $\mathrm{v}$ sotsialisticheskom obshchestve]. Sotsiologicheskie issledovaniya, 1, 215-234. 